\title{
Expression of periplasmic $\alpha$-amylase of Xanthomonas campestris K-11151 in Escherichia coli and its action on maltose
}

\author{
Jun-ichi Abe, Yuko Shibata, $†$ Mami Fujisue and Susumu Hizukuri
}

Author for correspondence: Susumu Hizukuri. Tel: +8199285 8640. Fax: +81992858640 .

e-mail: hizukuri@chem.agri.kagoshima-u.ac.jp

Department of Biochemical Science and Technology, Faculty of Agriculture, Kagoshima University, Korimoto-1 21-24,

Kagoshima 890, Japan

\begin{abstract}
A gene encoding the periplasmic $\alpha$-amylase of Xanthomonas campestris $K$ 11151 was cloned into Escherichia coli using pUC19 as a vector. An ORF of 1578 bp was deduced to be the amylase structural gene. The primary structure of the enzyme had little identity with other $\alpha$-amylases, except with the enzyme from Bacillus megaterium. The enzyme was expressed in $E$. coli from the lac promoter of pUC19 and was found to be transported to the periplasmic space. The expressed enzyme showed the same thermal stability, optimum temperature and substrate specificity as the enzyme from $X$. campestris. The

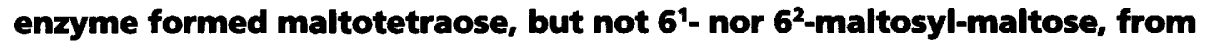
maltose by the reverse reaction, and the tetraose was then hydrolysed to maltotriose and glucose. The addition of maltotriose enhanced the production of glucose from maltose. In addition, maltose was formed by the condensation of glucose by the enzyme. Thus, the periplasmic $\alpha$-amylase of $X$. campestris was shown to produce glucose from maltose by hydrolysing maltotetraose and possibly higher maltooligosaccharides, which were the products of a condensation reaction, as a major pathway, and by direct hydrolysis of maltose as a minor pathway.
\end{abstract}

Keywords: heterologous expression, cyclodextrinase, maltose hydrolysis, condensation, dot-matrix analysis

\section{INTRODUCTION}

$\alpha$-Amylase is an important enzyme, not only for the starch industry, but also for structural studies on starch-related saccharides. Xanthomonas campestris K-11151, isolated from soil, produces an $\alpha$-amylase which has unique substrate specificity (Abe et al., 1994). It can hydrolyse $\alpha$ cyclodextrin $(\alpha-C D)$ into maltose and glucose at the same rate as that for soluble starch, and pullulan into panose with two-thirds of the velocity for soluble starch. Thus, the enzyme appears to have the mixed substrate specificity of $\alpha$-amylase, cytclodextrinase and neopullulanase. In addition, we found that the enzyme can produce glucose from maltose, which is not a normal substrate of $\alpha$ -

†Present address: Enzymology Research Laboratory, Nippon Gene Co. Ltd, Tonyamachi 1-29, Toyama 930, Japan.

Abbreviation: $\mathrm{CD}$, cyclodextrin.

The DDBJ accession number for the sequence reported in this paper is D38228. amylases. It would therefore be interesting to investigate the relationship between the structure and function of this enzyme in detail.

Here, we cloned the $\alpha$-amylase gene into Escherichia coli and sequenced it, deduced the primary enzyme sequence, and compared it to those of other amylases. We confirmed that the enzyme expressed in $E$. coli had the same properties as the original enzyme and then tried to find out the mechanism for glucose production from maltose by the enzyme.

\section{METHODS}

Materials. $X$. campestris $\mathrm{K}-11151$ has been maintained in our laboratory (Abe et al., 1994). E. coli XL-1 Blue $\{\Delta($ lac $)$ end $A 1$ gyr $A 96$ bsdR $17\left(\mathrm{r}_{\mathrm{k}}^{-} \mathrm{m}_{\mathrm{k}}^{+}\right) \operatorname{rec} A 1$ supE44 thi-1 $\left[\mathrm{F}^{\prime}\right.$ lac $I^{\mathrm{q}}$ lac $\mathrm{Z} \Delta \mathrm{M} 15$ pro $A B \operatorname{Tn} 10\left(\right.$ tet $\left.\left.\left.^{\mathrm{r}}\right)\right]\right\}$ and JM109 $\{\Delta($ lac-pro $A B)$ end $A 1$ gyr $A 96$ bsdR $17 \lambda^{-}$relA1 supE44 thi $\left[\mathrm{F}^{\prime}\right.$ lac $I^{\mathrm{q}}$ lac $Z \Delta \mathrm{M} 15$ pro $A B$ traD 36$\left.]\right\}$ were used for the construction of a gene library and for subcloning and general DNA manipulation, respectively. Plasmids pUC18 and pUC19 were used as vectors. 
Glucose was from Wako Pure Chemicals, and maltose, maltotriose, maltotetraose, maltopentaose and pullulan of the highest grade were kindly donated by Hayashibara Biochemical Laboratory. Glucose and oligosaccharides were purified on Shandon ODS-Hypersil 5 using water as eluant. Maltitol and maltotriitol were respectively prepared by the reduction of maltose and maltotriose with sodium borohydride and were purified on ODS-Hypersil 5. CDs were donated by Nihon Shokuhinkako. Soluble starch and glycogen (rabbit liver) were purchased from Katayama Chemical and Sigma. Potato amylopectin and amylose were isolated from starch by the method of Lansky et al. (1949) with minor modifications (Hizukuri et al., 1981).

DNA manipulation. General DNA manipulation was performed according to Sambrook et al. (1989). DNA fragments were recovered from agarose gels using GeneClean II (Bio 101). Plasmids were introduced into $E$. coli by electroporation using a $0 \cdot 1 \mathrm{~cm}$ cell $(1250 \mathrm{~V}, 200 \Omega, 25 \mu \mathrm{F})$ on a Gene Pulser (Nippon Bio-Rad). DNA sequencing was carried out on both strands using the Sequenase version 2.0 7-deaza kit (USB) and $\left[{ }^{35} \mathrm{~S}\right] \mathrm{dCTP} \alpha \mathrm{S}$ (Amersham), or an ALF DNA sequencer (Pharmacia Biotech) with the AutoRead Sequencing kit after creating nested deletions using ExoIII and S1 nucleases. For Southern blotting, a DNA fragment was labelled with digoxigenin-dUTP (Boehringer Mannheim) according to the manufacturer's instructions. All restriction enzymes were from Nippon Gene. Homologies between two protein sequences were analysed by PALIGN in PC/Gene release 6.6 (IntelliGenetics/Teijin).

Enzyme assays. The amylase and glucose-producing activities were assayed as reported previously by Abe et al. (1994). One unit $(1 \mathrm{U})$ is defined as the amount of enzyme that hydrolysed $1 \mu$ mol 1,4- $\alpha$-glucosidic linkage $\min ^{-1}$. Malate dehydrogenase and $\beta$-lactamase activities were measured by the methods of Smith (1983) and Bush \& Sykes (1984) using L-malic acid and ampicillin as substrates, respectively. Protein was estimated by measuring the $A_{280}$ using a Shimadzu UV-210A spectrophotometer.

Cloning of the $\alpha$-amylase gene. Chromosomal DNA of $X$. campestris was partially hydrolysed with SauBAI and the fragments of 3-6 kbp were isolated through electrophoresis on $0.8 \%$ agarose. The fragments were then ligated into the $\mathrm{Bam} \mathrm{HI}$ site of pUC19. The resulting plasmids were introduced into $E$. coli XL-1 Blue by electroporation, and the recombinants, which grew as white colonies on LB agar supplemented with ampicillin, X-Gal and IPTG, were selected on M9 minimal medium containing ampicillin, IPTG and $\alpha-C D$ as the sole carbon source.

Cell fractionation. The cells of E. coli JM109 harbouring pCX213 were grown on LB medium $(50 \mathrm{ml})$ containing ampicillin and IPTG overnight and were fractionated as reported previously by Abe et al. (1994).

Gel electrophoresis. Native PAGE and SDS-PAGE were done according to Davis (1964) and Weber \& Osborn (1969), respectively, on $7.5 \%(\mathrm{w} / \mathrm{v})$ gels.

Purification of $\alpha$-amylase. $X$. campestris K-11151 was cultivated in medium containing $0.5 \% \alpha-\mathrm{CD}, 2 \%(\mathrm{w} / \mathrm{v})$ polypeptone, $0 \cdot 2 \%$ yeast extract, $0 \cdot 14 \% \mathrm{KH}_{2} \mathrm{PO}_{4}, 0 \cdot 1 \% \mathrm{NH}_{4} \mathrm{NO}_{3}, 0.02 \%$ $\mathrm{MgSO}_{4} \cdot 7 \mathrm{H}_{2} \mathrm{O}, 0.001 \%$ each of $\mathrm{NaCl}, \mathrm{CaCl}_{2} \cdot 2 \mathrm{H}_{2} \mathrm{O}$, $\mathrm{MnCl}_{2} \cdot 4 \mathrm{H}_{2} \mathrm{O}$ and $\mathrm{FeCl}_{3} \cdot 6 \mathrm{H}_{2} \mathrm{O}, 7$ p.p.m. $\mathrm{ZnCl}_{2} \cdot 7 \mathrm{H}_{2} \mathrm{O}$, 5 p.p.m. $\mathrm{CuSO}_{4} \cdot 5 \mathrm{H}_{2} \mathrm{O}$ and 1 p.p.m. $\mathrm{H}_{3} \mathrm{BO}_{3}$ at $30^{\circ} \mathrm{C}$ for 24 h, and $\alpha$-amylase was purified as follows.

E. coli JM109(pCX213) was grown on LB agar medium containing $100 \mathrm{mg}$ ampicillin $\mathrm{ml}^{-1}$ and $1 \mathrm{mM}$ IPTG. The cells were then transferred to $5 \mathrm{ml}$ M9 minimal medium supplemented with $1 \% \alpha-C D$ instead of glucose as the carbon source, $2 \mu \mathrm{g}$ thiamin $\mathrm{ml}^{-1}, 100 \mu \mathrm{g}$ ampicillin $\mathrm{ml}^{-1}$ and $0.5 \mathrm{mM}$ IPTG and cultivated at $30^{\circ} \mathrm{C}$ overnight. The culture was transferred to $100 \mathrm{ml}$ of the medium and incubated for $18 \mathrm{~h}$. Cells (from $30 \times 100 \mathrm{ml}$ culture) were collected, washed with $30 \mathrm{mM}$ Tris (pH 8.0)/1 mM ED'TA/20\% (w/v) sucrose by centrifugation, and suspended in the same buffer. Lysozyme was added at a final concentration of $200 \mu \mathrm{g} \mathrm{ml}^{-1}$, the mixture was kept at $0^{\circ} \mathrm{C}$ for $1 \mathrm{~h}$ and then the supernatant was recovered after centrifugation. Pulverized ammonium sulfate was added over $30 \mathrm{~min}$ to give $80 \%$ saturation. After standing for $1 \mathrm{~h}$, the precipitate was collected by centrifugation, dissolved in $10 \mathrm{mMCHES}$ (pH 8.5) $/ 2 \mathrm{mM} \mathrm{CaCl}_{2} / 5 \mathrm{mM}$ mercaptoethanol and dialysed against the same buffer. The solution was passed through a column of CM-Toyopearl $650 \mathrm{M}(1.7 \times 15 \mathrm{~cm})$, which was equilibrated with the above CHES buffer, to remove lysozyme. The eluant was collected and combined, and its buffer was changed to $50 \mathrm{mM}$ sodium acetate $(\mathrm{pH} \mathrm{4.5)}$ containing $5 \mathrm{mM}$ mercaptoethanol and $1.4 \mathrm{M}$ ammonium sulfate. The solution was applied to a column of Phenyl-Toyopearl 650S $(1 \times 20 \mathrm{~cm})$. After washing the column with the buffer, enzyme was eluted with a linear gradient of ammonium sulfate $(1 \cdot 4-0 \mathrm{M}$, total $500 \mathrm{ml}$ ). The active fractions were combined and concentrated using an Amicon membrane PM-10, then the buffer was exchanged with $50 \mathrm{mM}$ sodium acetate $(\mathrm{pH} 4 \cdot 5) / 2 \mathrm{mM} \mathrm{CaCl}_{2} /$ $5 \mathrm{mM}$ mercaptoethanol.

$\mathbf{N}$-terminal sequencing. The $\mathrm{N}$-terminal sequence of the protein was determined using an Applied Biosystems 477A protein sequenator.

Action of enzyme on maltose or glucose. A reaction mixture $(5 \mathrm{ml})$ containing purified maltose or glucose $(0.9 \mathrm{M}), 2 \mathrm{mM}$ $\mathrm{CaCl}_{2}, 1 \mathrm{mM}$ DT'T and enzyme $(25 \mathrm{U})$ in $50 \mathrm{mM}$ sodium acetate ( $\mathrm{pH} 4.5$ ) was incubated at $45^{\circ} \mathrm{C}$, and samples were withdrawn at appropriate time intervals. The products were analysed by HPLC using a Tosoh HLC-803D pump fitted with a column of Wakosil-NH2 (Wako Pure Chemicals), a Tosoh refractometer RI-8000, a Shimadzu Chromatopac C-R6A, and using $75 \%$ $(\mathrm{v} / \mathrm{v})$ acetonitrile as eluant at $1.0 \mathrm{ml} \mathrm{min}^{-1}$. The tetraose fraction was collected, concentrated, and analysed by highperformance anion-exchange chromatography with a Dionex BioLC pump (Nippon Dionex) fitted with columns of Dionex Carbopac PA1 $(4 \times 250 \mathrm{~mm}$, two columns in series $)$ and a pulsed amperometric detector (PAD-1), using $20 \mathrm{mM}$ sodium acetate in $0.15 \mathrm{M}$ sodium hydroxide as eluant. Standard $6^{1}$ - and $6^{2}$ maltosyl-maltose were prepared by condensation of maltose by Pseudomonas isoamylase (Abe et al., 1988).

\section{RESULTS}

\section{Cloning of the $\alpha$-amylase gene}

Using shotgun cloning followed by direct selection for the capability of growth on $\alpha$-CD medium, two colonies out of 8000 transformants were obtained. The plasmids obtained from them were identical as revealed by restriction enzymic analysis; the plasmid was termed pCX2, and possessed a $4 \mathrm{kbp}$ insert. The restriction map is shown in Fig. 1.

A labelled BamHI fragment $(1.7 \mathrm{kbp})$ from pCX2 hybridized with BamHI- or PstI-digested chromosomal DNA of $X$. campestris $\mathrm{K}-11151$ and in each case gave a single band on Southern blot analysis (data not shown). 


\section{Subcloning and expression in E. coli}

The PstI-Pst I fragment of $\mathrm{pCX} 2$ was subcloned into pUC19 to give pCX21 and pCX22, which contained the Pst $\mathrm{I}$ fragment in the same and opposite directions compared to pCX2, respectively (Fig. 1). E. coli JM109(pCX21) produced the enzyme when IPTG was included in the medium, while pCX22 did not, even in the presence of IPTG. The amount of enzyme produced by E. coli JM109(pCX21) was fourfold higher than that produced by E. coli JM109(pCX2). The elimination of the first $800 \mathrm{bp}$ and $1100 \mathrm{bp}$ yielded pCX213 and pCX212, which gave 67 -fold and $25 \%$ of the productivity of E. coli JM109(pCX2), respectively.

A cell-free extract of E. coli JM109(pCX213) contained material which corresponded to the purified enzyme from $X$. campestris $\mathrm{K}-11151$ on native PAGE, while that of $E$. coli(pUC19) did not (Fig. 2a).

Seventy-six per cent of $\alpha$-amylase and $\beta$-lactamase activities were recovered in the periplasmic fraction of $E$. coli JM109(pCX213), while $86 \%$ of malate dehydrogenase activity was found inside the cell.

\section{Properties of the purified enzyme}

Typical purification steps are summarized in Table 1. The purified enzyme from $E$. coli JM109(pCX213) had the same specific activity as that of the original $\alpha$-amylase from $X$. campestris. The enzyme showed the highest activity for $\alpha$-CD hydrolysis at $55^{\circ} \mathrm{C}(\mathrm{pH} 4.5,15 \mathrm{~min}$ assay) and the enzyme was stable up to $50{ }^{\circ} \mathrm{C}(\mathrm{pH} 4 \cdot 5$, 30 min preincubation). These properties were the same as those of the enzyme from $X$. campestris $\mathrm{K}-11151$. The purified enzyme hydrolysed soluble starch, amylose and CDs at similar rates and showed two-thirds of the activity on amylopectin and pullulan. Glycogen was a poor substrate. These action specificities were identical to those of the original enzyme ('Table 2).

\section{Nucleotide sequence of the $\alpha$-amylase gene and deduced primary sequence of the enzyme}

The whole insert of pCX213 (2200 bp) and a small ApaI-BamHI fragment (see Fig. 1) of pCX2 (400 bp) were sequenced (Fig. 3). The GC content of the whole sequenced region was $89 \%$. Two ORFs were found which were at nucleotide positions 505-2097 and 517-2097. We concluded that the latter frame was likely to encode the $\alpha$-amylase (see Discussion). A putative ribosome-binding site was found $7 \mathrm{bp}$ upstream of the ATG codon but a promoter-like sequence was not found. The ORF consisted of $1581 \mathrm{bp}$, which coded for 526 amino acid residues. N-terminal sequencing of the enzymes from the original and recombinant strains showed that the sequences were identical from residue 31 . The $M_{\mathrm{r}}$ of the mature enzyme calculated from its deduced sequence was 54437, in agreement with the results $\left(M_{\mathrm{r}} 55000\right)$ of SDS-PAGE analysis of the enzymes (Fig. $2 b)$.

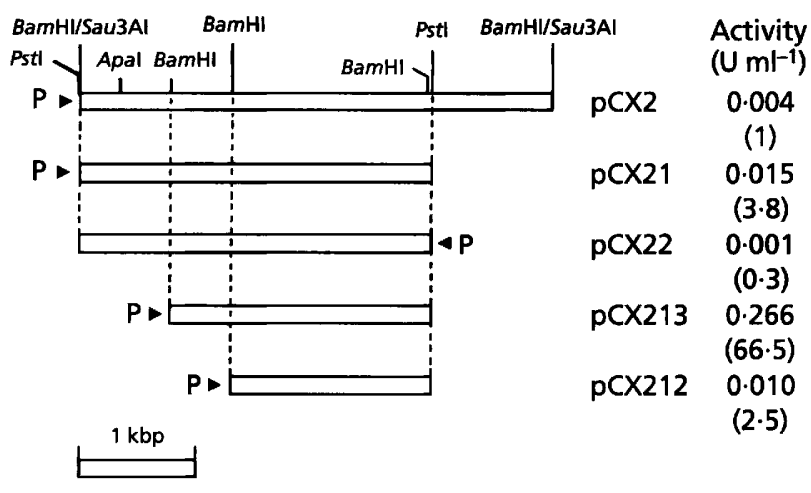

Fig. 1. Restriction maps and enzyme productivity of clones. PD, Direction of lac promoter. Relative activities of the recombinants compared to that of $\mathrm{pCX} 2$ are shown in parentheses. (a)

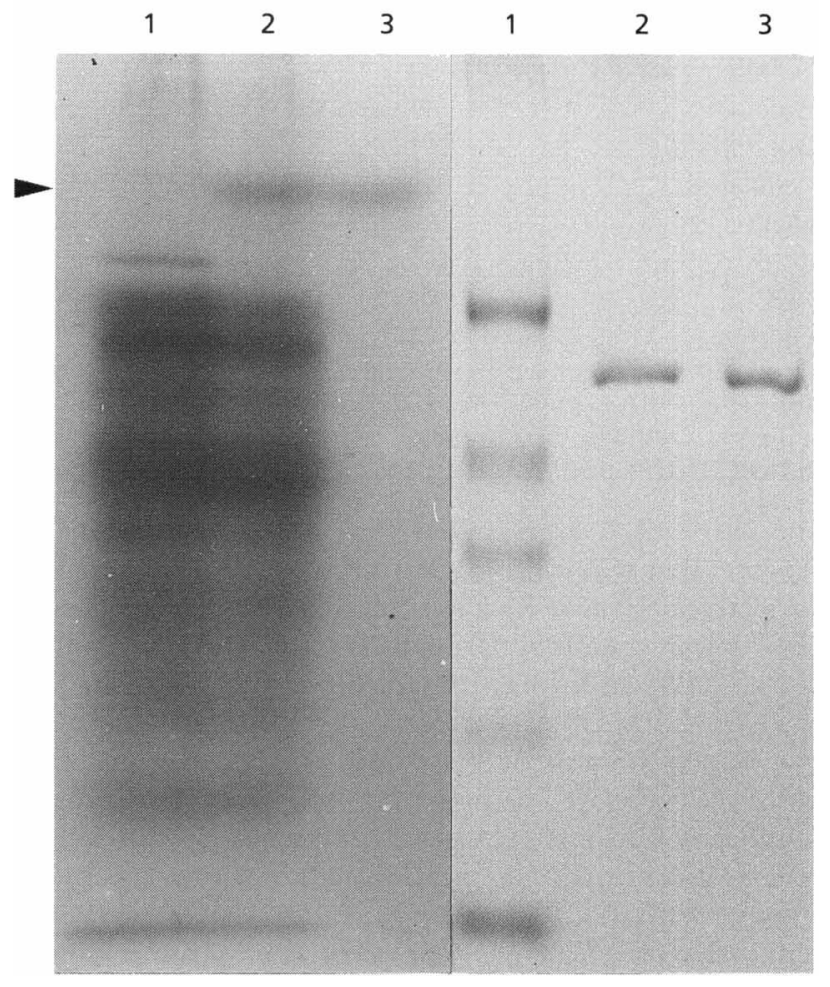

Fig. 2. Native PAGE of cell-free extracts (a) and SDS-PAGE of purified enzyme (b). (a) Lanes: 1 , extract from $E$. coli(pUC19); 2 , extract from $E$. coli( $(\mathrm{C} C \times 213) ; 3$, purified enzyme from $X$. campestris K-11151. (b) Lanes: 1, $M_{\mathrm{r}}$ markers: BSA (66000), ovalbumin (43000), glyceraldehyde-3-phosphate dehydrogenase (36000), chymotrypsinogen (25700) and myoglobin (17200); 2, purified enzyme of $X$. campestris K-11151; 3, purified enzyme from $E$. coli(pCX213).

The deduced primary sequence of the $\alpha$-amylase had four consensus regions (DLVINH as region 1, GFRLDAARH as region 2, EFRQ as region 3 and FLSNHD as region 4) for amylases as indicated in Fig. 3. 
Table 1. Summary of the purification of periplasmic $\alpha$-amylase expressed by $E$. coli JM109(pCX213)

\begin{tabular}{|lccccc|}
\hline Step & $\begin{array}{c}\text { Activity } \\
\text { (U) }\end{array}$ & $\begin{array}{c}\text { Protein } \\
\left(\boldsymbol{A}_{\mathbf{2 8 0}}\right)\end{array}$ & $\begin{array}{c}\text { Specific activity } \\
\text { (U per } \boldsymbol{A}_{\mathbf{2 8 0}} \text { unit) }\end{array}$ & $\begin{array}{c}\text { Purification } \\
\text { (-fold) }\end{array}$ & $\begin{array}{c}\text { Recovery } \\
\text { (\%) }\end{array}$ \\
\hline Crude extract & 925 & 466 & $1 \cdot 98$ & 1 & \\
Ammonium sulfate precipitation & 2590 & $51 \cdot 0$ & $50 \cdot 7$ & 26 & 100 \\
CM-Toyopearl 650M column & 2450 & $34 \cdot 9$ & $70 \cdot 1$ & 35 & 95 \\
Phenyl-Toyopearl column & 1450 & $9 \cdot 65$ & 150 & 76 & 56 \\
\hline
\end{tabular}

Table 2. Substrate specificity of enzymes from $X$. campestris K-11151 and E. coli JM109(pCX213)

All values are means of at least triplicate determinations, and all standard errors were less than $5 \%$.

\begin{tabular}{|lcc|}
\hline \multirow{2}{*}{ Substrate } & \multicolumn{2}{c|}{ Relative activity (\%) } \\
\cline { 2 - 3 } & $\begin{array}{c}\text { X. campestris } \\
\text { K-11151 }\end{array}$ & $\begin{array}{c}\text { E. coli } \\
\text { JM109(pCX213) }\end{array}$ \\
\hline Soluble starch & 100 & 100 \\
Amylose & 106 & 103 \\
Amylopectin & 64 & 61 \\
Pullulan & 65 & 66 \\
$\alpha$-CD & 95 & 94 \\
$\beta$-CD & 104 & 106 \\
$\gamma$-CD & 111 & 113 \\
Glycogen & $3 \cdot 2$ & $2 \cdot 6$ \\
\hline
\end{tabular}

\section{Action of the enzyme on maltose or glucose}

The activities of the $\alpha$-amylase on commercial and purified maltose relative to soluble starch were $0 \cdot 80$ and $0 \cdot 18$, respectively (Table 3 ). One per cent of maltotriose was detected in commercial maltose by HPLC (data not shown). The addition of purified maltotriose at the same ratio to the purified maltose gave a relative activity of $0 \cdot 74$, which was almost the same as that for the commercial maltose (Table 3 ). The production of glucose was further stimulated by the addition of maltotriose $(1: 20$ ratio of maltotriose to maltose, by mol), which alone was hydrolysed only scarcely (Table 3). Maltotetraose and maltopentaose were shown to be hydrolysed by the enzyme to produce glucose. Although the rate decreased, glucose was produced from a reaction containing a mixture of maltitol and maltotriose $(20: 1$, by mol) as the substrate. The enzyme did not produce any glucose in the reaction mixture which contained maltose and maltotriitol $(20: 1$, by mol) (Table 3 ).

The enzyme produced glucose from purified maltose gradually for $3 \mathrm{~h}$ and then rapidly, in agreement with the decrease of maltose and the appearance of maltotriose and maltotetraose (Fig. 4). The tetraose was neither $6^{1}$ - nor $6^{2}$ maltosyl-maltose since the retention times of $6^{1}$ - and $6^{2}$ maltosyl-maltose and maltotetraose were 25.6, 23.6 and 15.6 min, respectively, on the Carbopac PA1 column and the tetraose produced was eluted only at the maltotetraose position as a single peak. When glucose was used as substrate for the reverse reaction, HPLC analysis of the reaction mixture clearly showed the formation of maltose (Fig. 5).

\section{DISCUSSION}

Recombinant plasmid $\mathrm{pCX} 2$, which allowed E. coli to grow on minimal medium containing $\alpha-C D$ as the sole carbon source, contained a $4 \mathrm{kbp}$ fragment which was shown to originate from $X$. campestris chromosomal DNA by Southern hybridization analysis. The whole structural gene of $\alpha$-amylase seemed to be subcloned into pCX213 and expressed from the lac promoter on a pUC plasmid, since the productivity of the $\alpha$-amylase of $E$. coli JM109(pCX213) increased 67-fold compared to the E. coli JM109(pCX2) enzyme in the presence of IPTG, and native PAGE and SDS-PAGE of the enzyme preparations from E. coli JM109(pCX213) showed the same mobilities as those of the purified enzyme from $X$. campestris $\mathrm{K}$ 11151.

The enzyme was transported to the periplasmic space of E. coli JM109 as in the case of $X$. campestris $\mathrm{K}-11151$, and since the enzyme productivity of E. coli JM109(pCX213) was fivefold higher than the original strain and the transformant could grow on a synthetic medium, the enzyme purification became much easier, with higher recovery. The amount of enzyme activity after ammonium precipitation was usually higher than that in the crude enzyme. This might be due to some interfering substance which could be eliminated by fractionation by ammonium sulfate and/or following dialysis. The recoveries of the enzyme were calculated by taking the amount of the enzyme at this step as $100 \%$. The enzyme, which was produced by the transformant in its periplasmic space, had an identical N-terminal sequence to the enzyme from $X$. campestris, indicating that its signal sequence worked properly in E. coli, and the enzymes had almost the same properties, i.e. same specific activity, maximum temperature and thermal stability, and substrate specificity, suggesting that the correct folding of the protein occurred.

Although sequencing of the DNA fragments allowed two ORFs, namely nucleotides 505-2097 and 517-2097, to be identified, the second ATG (517-519) was likely to be the initiation codon because: (a) a putative ribosomebinding site was found only in this case (GGAG at -10 to -7 ), (b) glutamic acid as the second amino acid in a 


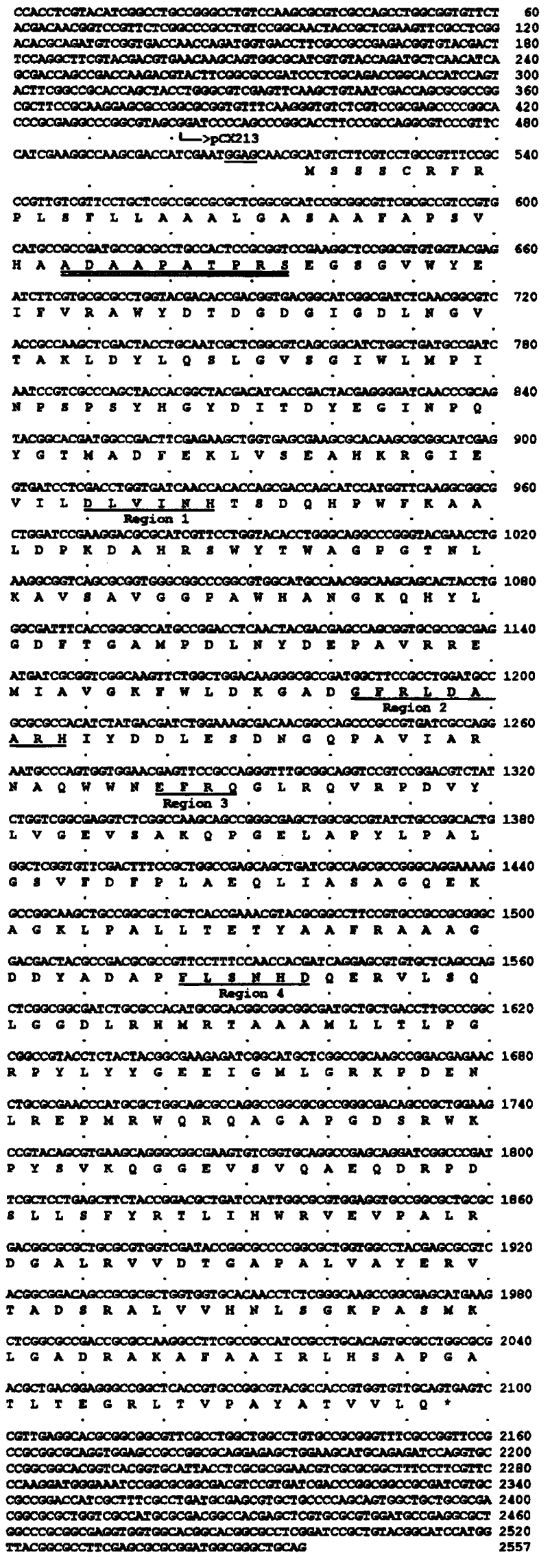

Table 3. Glucose-forming activity of $\alpha$-amylase from $E$. coli JM109(pCX213)

\begin{tabular}{|lc|}
\hline Substrate* & Relative activity $\dagger$ \\
\hline Commercial maltose & 0.80 \\
Maltose & 0.18 \\
Maltotriose & 0.02 \\
Maltotetraose & 0.75 \\
Maltopentaose & 0.75 \\
Maltitol & $<0.01$ \\
Maltotriitol & $<0.01$ \\
Maltose + maltotriose $\ddagger$ & 0.74 \\
Maltose + maltotriose $\$$ & 1.34 \\
Maltose + maltotriitol $\$$ & 0.03 \\
Maltitol + maltotriose $\$$ & 0.56 \\
\hline
\end{tabular}

* Substrate concentration was $1 \%(\mathrm{w} / \mathrm{v})$ unless indicated.

† Activity for soluble starch was taken as 100 . All values are means of at least triplicate determinations, and all standard errors were less than $5 \%$.

$\ddagger$ The ratio of maltotriose to maltose was $1: 100$ (by mol).

The ratio of maltotriose or maltotriitol to maltose or maltitol was $1: 20$ (by mol).

signal peptide (encoded by the ORF at 505) does not agree with the general structure of bacterial signal peptides (Pugsley, 1993), and (c) the N-terminal amino acid sequence of the putative signal peptide, particularly the position of the positively charged residue Arg, which was four to five residues away from the first Met, was quite similar to those of avirulence protein (Parker et al., 1992), endoglucanase (Gough et al., 1990) and extracellular $\alpha$ amylase (Hu et al., 1992) from $X$. campestris; the sequences Met- $(\mathrm{X})_{3-4}$-Arg- are in accordance with the general signal peptide structure (Pugsley, 1993). We could not find a promoter-like sequence, suggesting that this gene was linked to others; however, the gene was functional under the lac promoter on a pUC plasmid and produced $1.3 \mathrm{U}$ $(\mathrm{ml} \text { culture })^{-1}$, fivefold higher than the productivity of the original strain, $X$. campestris $\mathrm{K}-11151$. The deduced primary sequence of the enzyme showed 30 amino acid residues for the signal peptide and 496 amino acid residues for the mature enzyme. The $M_{\mathrm{r}}$ was calculated to be 54437 , which was in good agreement with the result of the SDS-PAGE.

The enzyme had four regions (Nakajima et al., 1986) commonly found in many amylases (marked in Fig. 3). We deduced that D197, E225 and D311 corresponded to the essential residues of Taka-amylase (Matsuura et al.,

Fig. 3. Nucleotide sequence of the DNA fragment containing the $\alpha$-amylase gene. A putative ribosome-binding site and a sequence which agreed with the results of $\mathrm{N}$-terminal sequencing of the purified native and recombinant enzymes are singly and doubly underlined, respectively. Regions 1-4 are the consensus sequences found in amylases (see text). 

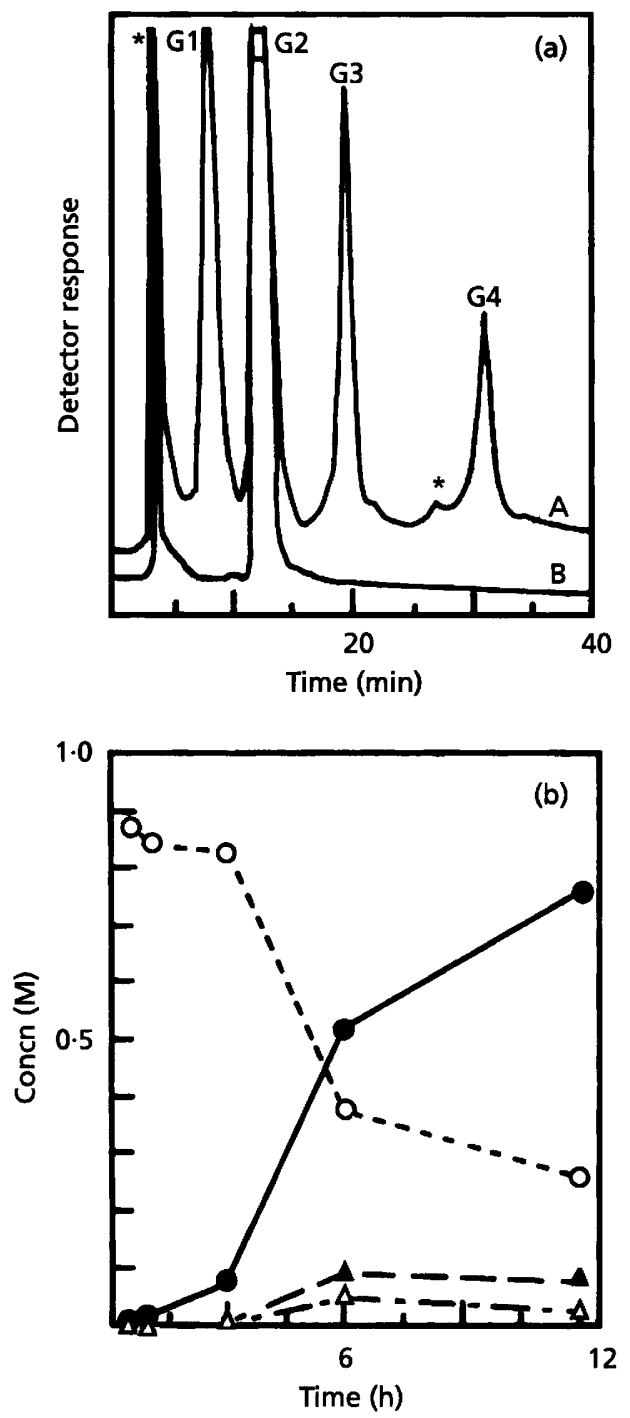

Fig. 4. HPLC chromatogram of the reaction products from maltose after $6 \mathrm{~h}$ (a) and determination of each product (b). Products were analysed by HPLC using $75 \%(\mathrm{v} / \mathrm{v})$ acetonitrile as eluant. A, Reaction products; B, purified maltose used as substrate; $G 1$ and $O$, glucose; $G 2$ and $O$, maltose; $G 3$ and $A$. maltotriose; $\mathrm{G} 4$ and $\triangle$, maltotetraose. The peaks marked by an asterisk were due to the buffer and/or enzyme.

1984), D206, E230 and D297, respectively, by the comparison of the primary sequences. The low degree of identity $(14 \%)$ and the result of dot-matrix analysis (Fig. 6a) showed that the periplasmic $\alpha$-amylase of $X$. campestris was a different enzyme from the reported extracellular enzyme (Hu et al., 1992). The periplasmic enzyme showed $44 \%$ identity to the Bacillus magaterium $\alpha$-amylase (Metz et al., 1988; Fig. 6b), which can also act on starch-related materials, pullulan and CDs (Brumm et al., 1991a), but has a slightly different substrate specificity in that the rate for $\alpha$-CD is less than $20 \%$ of those for $\beta$ - and $\gamma$-CDs, and glycogen is a better substrate than pullulan, amylose and amylopectin. The primary sequence of the periplasmic $\alpha$ amylase from $X$. campestris $\mathrm{K}-11151$ showed a low degree

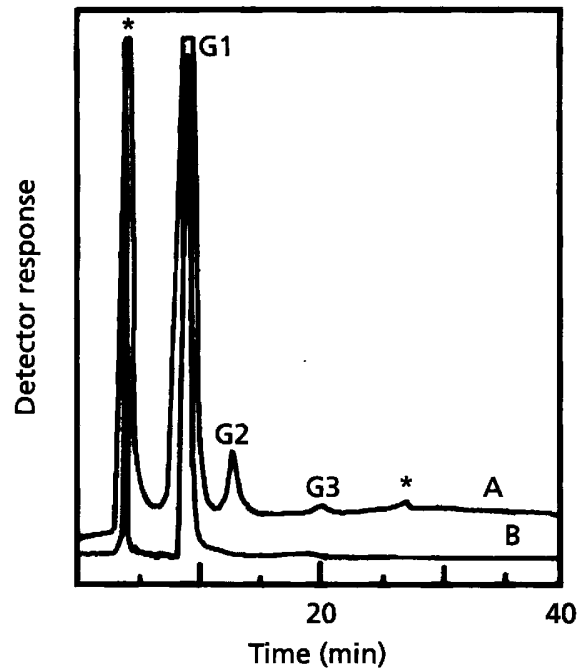

Fig. 5. Determination of reaction products from glucose. A reaction mixture containing purified glucose was incubated at $45^{\circ} \mathrm{C}$ for $6 \mathrm{~h}$ and products were analysed by HPLC. A, Reaction products; B, purified glucose used as substrate. G1, Glucose; G2, maltose; G3, maltotriose. The peaks marked by an asterisk were due to the buffer and/or enzyme.

of identity with cyclodextrinase from Thermoanaerobacter ethanolicus (Podkovyrov \& Zeikus, 1992) (18\%; Fig. 6c) and neopullulanase from Bacillus stearothermophilus (Kuriki \& Imanaka, 1989) (19\%; Fig. 6d), although it has both activities. The latter two enzymes have $48 \%$ identity and differ from the general $\alpha$-amylase in having an additional domain, as indicated by Jaspersen et al. (1991). The enzyme showed $13 \%, 10 \%$ and $6 \%$ identity, respectively, to Taka-amylase (Toda et al., 1982), Bacillus subtilis $\alpha$ amylase (Yamazaki et al., 1983) and porcine pancreatic $\alpha$ amylase (Pasero et al., 1986), and similar values were found to most other $\alpha$-amylases.

In a previous paper, we mentioned that the enzyme has the ability to degrade maltose to glucose (Abe et al., 1994). However, the purified enzyme was found to have a rather low activity on purified maltose (Table 3 ). In this study, we clearly show that the main pathway of maltose degradation by the enzyme is the hydrolysis of maltotetraose to maltotriose and glucose after condensation of two maltose molecules into a maltotetraose molecule (Fig. 4). It was noted that the condensation product was neither $6^{1}$ - nor $6^{2}$-maltosyl-maltose, but maltotetraose. Thus, the enzyme could form a 1,4- $\alpha$-glucosidic linkage via a condensation reaction. This type of condensation was the same as in the case of the B. megaterium $\alpha$-amylase (Brumm et al., 1991b).

The reconstituted commercial maltose, which was prepared by mixing 99 parts purified maltose and 1 part purified maltotriose (by $\mathrm{mol}$ ), gave almost the same hydrolysis rate as that for commercial maltose (Table 3 ). Moreover, the addition of maltotriose (1:20 maltotriose to maltose, by mol) greatly stimulated the release of glucose. This suggests that the rather high activity of the 
(a)
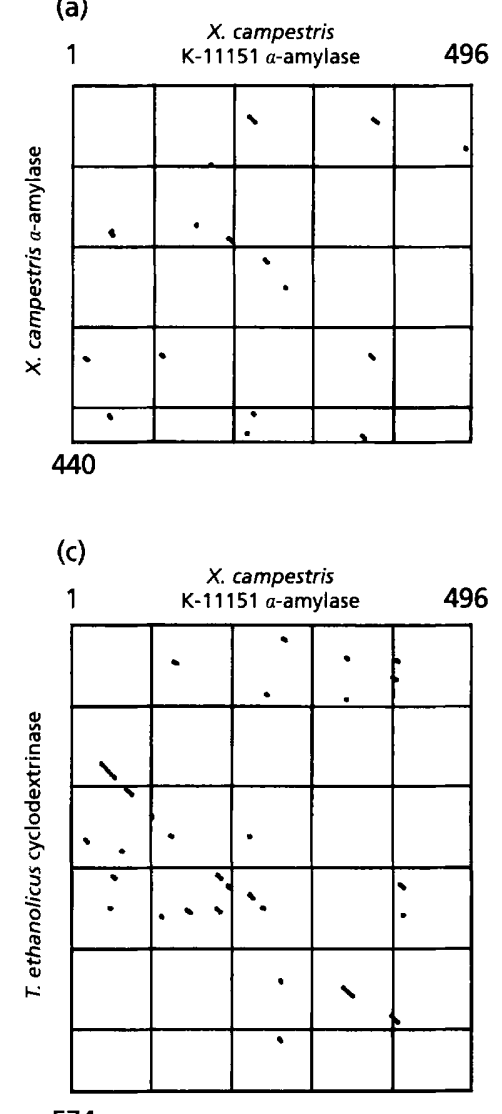

(b)

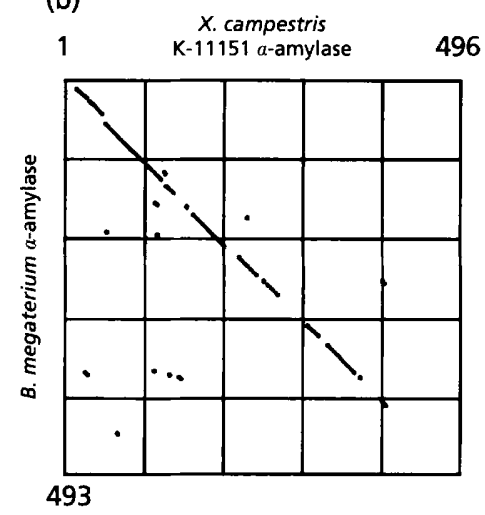

(d)

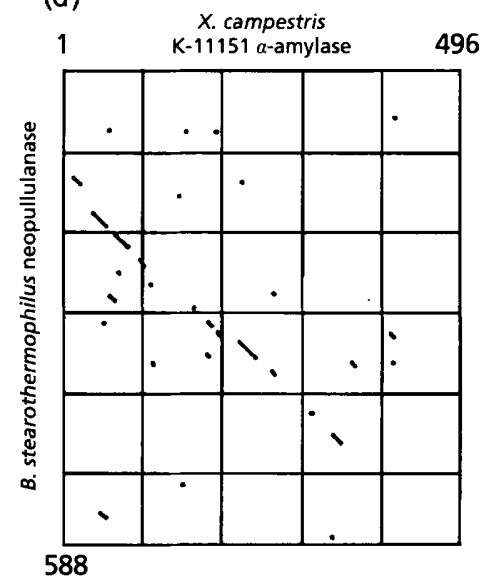

Fig. 6. Dot-matrix analyses of primary sequences of amylases. (a) $X$. campestris $\mathrm{K}$ 11151 periplasmic $\alpha$-amylase (XCPAMY) versus $X$. campestris extracellular $\alpha$-amylase (Hu et al., 1992); (b) XCPAMY versus $B$. megaterium $\alpha$-amylase (Metz et al., 1988); (c) XCPAMY versus $T$. ethanolicus cyclodextrinase (Podkovyrov \& Zeikus, 1992); (d) XCPAMY versus $B$. stearothermophilus neopullulanase (Kuriki \& Imanaka, 1989). enzyme for the commercial maltose was due to the stimulation of the condensation by the low amount of maltotriose, followed by the release of glucose from maltopentaose. As shown in Table 3, the enzyme has the ability to produce glucose from this sugar. When maltotriitol instead of maltotriose was added to maltose, glucose production decreased drastically, while stimulation was still observed when the reaction mixture contained maltitol and maltotriose (20:1, by mol; Table 3$)$. These results clearly show that maltotriose and maltose are predominantly accommodated at the positions for a donor and an acceptor, respectively, at the active site during condensation of the mixed substrate and the binding affinity of maltotriose to the former site is very strong. Maltotriitol also binds to the donor site, and therefore glucose production from the mixture containing this substrate was reduced. Thus, the substrate-binding site of the enzyme which accommodates the non-reducing terminal glucosyl residue of maltotriose and maltotriitol appears to have very high affinity. Considering both the condensation ability of this enzyme and the crosscontamination of oligosaccharide preparations, we may need to reevaluate thoroughly the action of this enzyme on oligosaccharides in a future study.

During the reaction on maltose, condensation occurs to form maltotetraose and possibly higher maltooligosaccharides; those oligosaccharides and breakdown products from them must then serve as donors or receptors for further condensation or possible transglucosidation reactions. Thus, the total reaction of glucose formation from maltose could be very difficult to resolve clearly.

In these experiments, we could not identify whether a mechanism for direct hydrolysis of maltose is present; however, we could detect the formation of maltose and maltotriose as products of the reverse action using purified glucose as substrate. This suggests that the enzyme has a possible function in direct maltose breakdown, although the rate would be very low.

\section{ACKNOWLEDGEMENTS}

This work was supported in part by Grants-in-Aid for Cooperative Research (A) (no. 05303010) from the Ministry of Education, Science and Culture of Japan.

\section{REFERENCES}

Abe, J., Hizukuri, S., Koizumi, K., Kubota, Y. \& Utamura, T. (1988). Enzymic syntheses of doubly-branched cyclomaltoheptaose through the reverse action of Pseudomonas isoamylase. Carbobydr Res 176, 87-95.

Abe, J., Onitsuka, N., Nakano, T., Shibata, Y., Hizukuri, S. \& Entani, E. (1994). Purification and characterization of periplasmic $\alpha$ amylase from Xanthomonas campestris K-11151. J Bacteriol 176, 3584-3588.

Brumm, P. J., Hebeda, R. E. \& Teague, W. M. (1991a). Purification and characterization of the commercialized, cloned Bacillus mega- 
terium $\alpha$-amylase. Part I. Purification and hydrolytic properties. Starch Staerke 43, 315-319.

Brumm, P. J., Hebeda, R. E. \& Teague, W. M. (1991b). Purification and characterization of the commercialized, cloned Bacillus megaterium $\alpha$-amylase. Part II. Transferase properties. Starch Staerke 43, 319-323.

Bush, K. \& Sykes, R. B. (1984). $\beta$-Lactamase (penicillinase, cephalosporinase). In Methods of Envymatic Analysis, vol. IV, pp. 280-285. Edited by H. U. Bergmeyer, H. J. Bergemeyer \& M. Graßl. Weinheim: Verlag Chemie.

Davis, B. J. (1964). Disc electrophoresis. II. Method and application to human serum proteins. Ann NY Acad Sci 121, 404-427.

Gough, C. L., Dow, J. M., Keen, J., Henrissat, B. \& Daniels, M. J. (1990). Nucleotide sequence of the eng XCA gene encoding the major endoglucanase of Xanthomonas campestris pv, campestris. Gene 89, 53-59.

Hizukuri, S., Takeda, Y., Yasuda, M. \& Suzuki, A. (1981). Multibranched nature of amylose and the action of debranching enzyme. Carbobydr Res 94, 205-213.

Hu, N. T., Hung, M. N., Huang, A. M., Tsai, H. F., Yang, B. Y., Chow, T. Y. \& Tseng, Y. H. (1992). Molecular cloning, characterization and nucleotide sequence of the gene for secreted $\alpha$ amylase from Xanthomonas campestris pv. campestris. J Gen Microbiol $138,1647-1655$.

Jaspersen, H. M., MacGregor, E. A., Sierks, M. R. \& Svensson, B. (1991). Comparison of the domain-level organization of starch hydrolases and related enzymes. Biocbem $J$ 280, 51-55.

Kuriki, T. \& Imanaka, T. (1989). Nucleotide sequence of the neopullulanase gene from Bacillus stearotbermopbilus. J Gen Microbiol $135,1521-1528$.

Lansky, S., Kooi, M. \& Shhoch, T. J. (1949). Properties of the fractions and linear subfractions from various starches. $J \mathrm{Am} \mathrm{Chem}$ Soc 71, 4066-4075.

Matsuura, Y., Kusunoki, M., Harada, W. \& Kakudo, M. (1984). Structure and possible catalytic residues of Taka-amylase A. $J$ Biochem 95, 697-702.

Metz, R. J., Allen, L. N., Cao, T. M. \& Zeman, N. W. (1988). Nucleotide sequence of an amylase gene from Bacillus megaterium. Nucleic Acids Res 16, 5203.
Nakajima, R., Imanaka, T. \& Aiba, S. (1986). Comparison of amino acid sequences of eleven different $\alpha$-amylases. Appl Microbiol Biotechnol 23, 355-360.

Parker, J. E., Barber, C. E., Mi-Jiao, F. \& Daniels, M. J. (1992). Interaction of Xanthomonas campestris with Arabidopsis thaliana: characterization of a gene from Xanthomonas campestris pv. raphani that confers avirulence to most $A$. thaliana accessions. Mol Plant-Microbe Interact 6, 216-224.

Pasero, L., Mazzei-Pierron, Y., Abadie, B., Chicheportiche, Y. \& Marchis-Mouren, G. (1986). Complete amino acid sequence and location of the five disulfide bridges in porcine pancreatic $\alpha$ amylase. Biocbim Biopbys Acta 869, 147-157.

Podkovyrov, S. M. \& Zeikus, J. G. (1992). Structure of the gene encoding cyclomaltodextrinase from Clostridium thermobydrosulfuricum $39 \mathrm{E}$ and characterization of the enzyme purified from Escbericbia coli. J Bacteriol 174, 5400-5405.

Pugsley, A. P. (1993). The complete general secretory pathway in Gram-negative bacteria. Microbiol Rev 57, 50-108.

Sambrook, J., Fritsch, E. F. \& Maniatis, T. (1989). Molecular Cloning: a Laboratory Manual, 2nd edn. Cold Spring Harbor, NY: Cold Spring Harbor Laboratory.

Smith, A. F. (1983). Malate to oxaloacetate reaction. In Methods of Enzymatic Analysis, vol. III, pp. 166-171. Edited by H. U. Bergmeyer, H. J. Bergemeyer \& M. Graßl. Weinheim: Verlag Chemie.

Toda, H., Kondo, K. \& Narita, K. (1982). The complete amino acid sequence of Taka-amylase A. Proc Jpn Acad 58B, 208-212.

Yamazaki, H., Ohmura, K., Nakayama, A., Takeichi, Y., Otozai, K., Yamasaki, M., Tamura, G. \& Yamane, K. (1983). $\alpha$-Amylase genes (amyR2 and amyE(+)) from an $\alpha$-amylase-hyperproducing Bacillus subtilis strain: molecular cloning and nucleotide sequences. $J$ Bacteriol 156, 327-337.

Weber, K. \& Osborn, M. (1969). The reliability of molecular weight determination by dodecyl sulfate-polyacrylamide gel electrophoresis. J Biol Chem 244, 4406-4412.

Received 13 November 1995; revised 3 January 1996; accepted 15 January 1996. 